\title{
A Multi-Enzymatic Cascade Reaction for the Synthesis of Vidarabine 5'-Monophosphate
}

\author{
Marina Simona Robescu ${ }^{1}{ }^{1}$, Immacolata Serra ${ }^{2, *}$, Marco Terreni ${ }^{1}$, Daniela Ubiali ${ }^{1, *}$ and \\ Teodora Bavaro ${ }^{1}$ (D) \\ 1 Department of Drug Sciences, University of Pavia, viale Taramelli 12, I-27100 Pavia, Italy; \\ marinasimona.robescu@unipv.it (M.S.R.); marco.terreni@unipv.it (M.T.); teodora.bavaro@unipv.it (T.B.) \\ 2 Department of Food, Environmental and Nutritional Sciences, University of Milan, via Mangiagalli 25, \\ I-20133 Milano, Italy \\ * Correspondence: immacolata.serra@unimi.it (I.S.); daniela.ubiali@unipv.it (D.U.); Tel.: +39-02-50319248 (I.S.); \\ +39-0382-987889 (D.U.)
}

Received: 4 December 2019; Accepted: 27 December 2019; Published: 1 January 2020

check for updates

\begin{abstract}
We here described a three-step multi-enzymatic reaction for the one-pot synthesis of vidarabine 5'-monophosphate (araA-MP), an antiviral drug, using arabinosyluracil (araU), adenine (Ade), and adenosine triphosphate (ATP) as precursors. To this aim, three enzymes involved in the biosynthesis of nucleosides and nucleotides were used in a cascade mode after immobilization: uridine phosphorylase from Clostridium perfringens (C $p \mathrm{UP})$, a purine nucleoside phosphorylase from Aeromonas hydrophila (AhPNP), and deoxyadenosine kinase from Dictyostelium discoideum (DddAK). Specifically, C $p$ UP catalyzes the phosphorolysis of araU thus generating uracil and $\alpha$-D-arabinose-1-phosphate. AhPNP catalyzes the coupling between this latter compound and Ade to form araA (vidarabine). This nucleoside becomes the substrate of DddAK, which produces the $5^{\prime}$-mononucleotide counterpart (araA-MP) using ATP as the phosphate donor. Reaction conditions (i.e., medium, temperature, immobilization carriers) and biocatalyst stability have been balanced to achieve the highest conversion of vidarabine $5^{\prime}$-monophosphate ( $\left.\geq 95.5 \%\right)$. The combination of the nucleoside phosphorylases twosome with deoxyadenosine kinase in a one-pot cascade allowed (i) a complete shift in the equilibrium-controlled synthesis of the nucleoside towards the product formation; and (ii) to overcome the solubility constraints of araA in aqueous medium, thus providing a new route to the highly productive synthesis of araA-MP.
\end{abstract}

Keywords: enzyme cascade; enzyme immobilization; vidarabine 5'-monophosphate; nucleoside phosphorylase; deoxyadenosine kinase; transglycosylation; phosphorylation; unnatural nucleosides

\section{Introduction}

Nucleoside and nucleotide analogues are synthetic, chemically modified molecules that can mimic the natural building blocks of DNA/RNA synthesis; they can act, indeed, as antimetabolites, thus exerting anticancer/antiviral effects [1]. Upon cellular uptake, nucleosides are activated in vivo to $5^{\prime}$-triphosphates by a sequential phosphorylation reaction catalyzed by host cell kinases or virus-encoded kinases. This means that nucleoside analogues must not only be substrates for polymerases, they also need to be recognized and phosphorylated by kinases [2]. Once phosphorylated, nucleotide analogues can elicit their effects by impairing nucleic acid synthesis [3].

Some modified nucleosides are frequently used as $5^{\prime}$-monophosphate prodrugs. The use of 5 '-monophosphates allows both for circumventing the poor water solubility of the parent nucleosides and the first activation step through phosphorylation which is often a rate-limiting reaction [2]. This is the case of the antiviral drug vidarabine (Vira- $A^{\circledR}$, arabinosyladenine, araA) which was the first of 
the FDA-approved nucleoside analogues to be administered systemically in clinics [4]. Similarly, the 2-fluorinated counterpart of vidarabine (Fludara ${ }^{\circledR}$, arabinosyl-2-fluoroadenine $5^{\prime}$-monophosphate, F-araA-MP) is used as $5^{\prime}$-monophosphate in the treatment of haematological malignancies [5].

Chemical methods for nucleoside/nucleotide synthesis involve multi-step routes [6,7] which often require harsh reaction conditions and are plagued by moderate yields.

In recent decades, several biocatalytic approaches have been described exploiting enzymes that are naturally involved in the biosynthesis of nucleosides and nucleotides such as nucleoside phosphorylases (NPs, EC 2.4.2.x) and deoxyribonucleoside kinases (dNKs, EC 2.7.1.x) [8-13]. NPs act in the salvage pathway of nucleobases and catalyze the reversible conversion of (deoxy)ribonucleosides to their corresponding free base and $\alpha$-D-(deoxy)ribose-1-phosphate in the presence of inorganic orthophosphate (phosphorolysis). The reversibility of phosphorolysis reaction can be exploited for synthetic applications: if a second nucleobase reacts with $\alpha$-D-(deoxy)ribose-1-phosphate, the formation of a new nucleoside can result (transglycosylation) [10]. dNKs catalyze the transfer of the $\gamma$-phosphate group from a nucleotide (generally ATP) to the $5^{\prime}$-hydroxyl group of nucleosides thus forming the corresponding 5'-mononucleotide [14]. The potential of NPs and dNKs in the synthesis of nucleoside/nucleotide analogues has been already demonstrated by several papers published in recent years [9-12,15-17]. Uridine phosphorylase from Clostridium perfringens (C $p \mathrm{UP}$ ) and a purine nucleoside phosphorylase from Aeromonas hydrophila (AhPNP) were used in the preparative synthesis of araA yielding $3.5 \mathrm{~g} / \mathrm{L}$ of the desired product (purity 98.7\%) [18]. Moreover, an enzymatic approach for the phosphorylation of araA to araA-MP and of F-araA to F-araA-MP using either a deoxyribonucleoside kinase from Drosophila melanogaster (DmdNK) [11], a deoxyadenosine kinase from Dictyostelium discoideum (DddAK) [12], or human deoxycytidine kinase (HsdCK) [17] has been developed.

Biocatalysts are not only environmentally benign reagents and highly selective, but they are compatible with each other within certain ranges of operating conditions [19,20]. This feature enables integration of sequential biocatalytic transformations in one-pot cascades for the synthesis of complex molecules [21]. The design of enzymatic networks in one-pot systems, as occurring in living cells, has evident advantages allowing the increase of reaction rate, higher yields and also overcoming substrate/product inhibition [22]. Moreover, running artificial cascades using immobilized biocatalysts can provide a spatial compartmentalization of each biocatalyst thus favoring substrate channeling [23]. Using immobilized multi-enzyme systems allows the recycling of the biocatalysts, simplifies the downstream processing, and improves enzyme stability with evident benefits for process economics. Immobilization can also affect the microenvironment surrounding the biocatalyst and, indeed, its catalytic properties. By fine-tuning the carrier properties in terms of charge or hydrophilicity/lipophilicity, enzyme performance can be modulated [24-26] and customized for each process.

In this work we reported on the design of a one-pot linear cascade reaction based on the sequential ("tandem") use of three enzymes by coupling the transglycosylation reaction catalyzed by immobilized $C p \mathrm{UP}$ and $A h \mathrm{PNP}$ to give araA [18] and the $5^{\prime}$-phosphorylation of araA into araA-MP catalyzed by DddAK [12] (Scheme 1 and Figure S1).

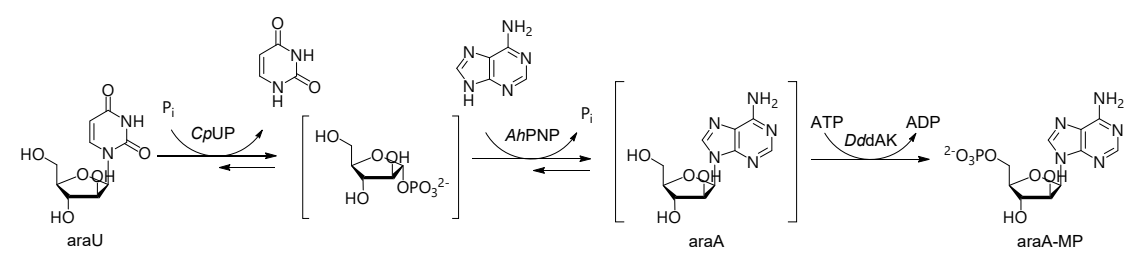

Scheme 1. Three-enzyme cascade reaction for the synthesis of araA-MP. Legend: araU (arabinosyluracil), $\mathrm{P}_{\mathrm{i}}$ (inorganic orthophosphate), araA (arabinosyladenine or vidarabine), araA-MP (vidarabine- $5^{\prime}$-monophosphate), ATP (adenosine 5'-triphosphate), ADP (adenosine 5'-diphosphate). Biocatalysts: C $\mathrm{UP}$ (uridine phosphorylase from Clostridium perfringens), AhPNP (purine nucleoside phosphorylase from Aeromonas hydrophila), DddAK (deoxyadenosine kinase from Dictyostelium discoideum). 


\section{Results and Discussion}

\subsection{A Three-Enzyme Cascade for the Synthesis of araA-MP}

Developing a multi-enzyme system requires a deep understanding of each single biotransformation to set-up a concerted and viable reaction. The challenge is to tune conditions in each bioconversion step for catalyst activity and stability (i.e., medium, temperature, $\mathrm{pH}$ ) as well as substrate specificity. Therefore, the starting point of this work were the results previously achieved (see Introduction) in the synthesis of araA by NP-catalyzed transglycosylation [18] and in the kinase-catalyzed phosphorylation of araA [12], with the aim to integrate these biotransformations and demonstrate the feasibility of the multi-enzyme cascade (Scheme 1 and Figure S1).

Specifically, two are the main advantages envisaged for running the synthesis of vidarabine $5^{\prime}$-monophosphate in a linear multi-enzymatic one-pot cascade: (i) transglycosylation is an equilibrium-controlled reaction. Once that it is coupled to the phosphorylation, that is irreversible, the equilibrium can be shifted towards the product formation; (ii) the final product (araA-MP) is water soluble. Therefore, the drawback of poor water solubility of vidarabine [18] can be overcome because as soon as the nucleoside is formed, it is converted in the soluble monophosphate. This strategy allows to perform the reaction in fully aqueous medium and results into an easier scale-up of the biotransformation. In this case, $\mathrm{N}, \mathrm{N}$-dimethylformamide (DMF), which was required as a co-solvent in the gram scale synthesis of araA by a one-pot transglycosylation [18], could be avoided, thus increasing the greenness of the bioprocess.

A further advancement of the cascade design, still related to the equilibrium-controlled transglycosylation (first two steps of Scheme 1), is the use of a reduced amount of the nucleoside acting as the "sugar donor" (araU, Scheme 1). In the "one-pot, two-enzyme" synthesis of araA by transglycosylation (Figure S1) a 2:1 molar excess of araU was used to shift the biotransformation toward the product formation. However, the highest conversion achieved was $80 \%$ [18]. The additional increase of the molar ratio of the "sugar donor", albeit araU is commercially available at a reasonable cost, would still not be beneficial for economic reasons (cost of the reagent) and because it would result in the formation of a higher amount of uracil (by-product) and a poorer atom economy, thereof. In the cascade mode, the use of an excess of araU was indeed avoided since a 1:1 molar ratio of the reagents (araU and adenine) was sufficient to achieve a quantitative conversion as a result of the equilibrium shift due to the action of $D d \mathrm{dAK}$ (with a positive effect on cutting costs and waste generation).

All the enzymes were used as immobilized biocatalysts according to our previous investigations. Thus, C $p$ UP and AhPNP were used upon covalent immobilization on glyoxyl-agarose [18], whereas DddAK was immobilized by a ionic interaction on an epoxy carrier (Sepabeads ${ }^{\circledR}$ EC-EP) previously coated with polyethylenimine (PEI), followed by cross-linking with a polyaldehyde (CL) $[12,27]$. In agreement also with recent reports [25,26], this latter approach results in a sort of "co-immobilization" of the co-factor (ATP, in this case), thus ensuring a self-sufficient source of it for an efficient catalysis. On the other hand, $C p \mathrm{UP}$ and $A h \mathrm{PNP}$ immobilized on glyoxyl-agarose were active and stable in the continuum synthesis of araA both in batch [18] and in a flow mode (unpublished data).

\subsubsection{Reaction Temperature and $\mathrm{pH}$}

From our previous investigations, temperature might have been a critical parameter. In fact, a temperature higher than $37^{\circ} \mathrm{C}$ was found to be detrimental for DddAK [12]. It was thus natural to run the reaction at $37^{\circ} \mathrm{C}$ and at $25^{\circ} \mathrm{C}$ for a comparative evaluation. The temperature affects reaction kinetics and, as expected, the reaction at $37^{\circ} \mathrm{C}$ had a 2.5 -fold faster kinetics, although after $24 \mathrm{~h}$ the highest conversion $(>95 \%)$ was reached also by the reaction run at $25^{\circ} \mathrm{C}$. For setting-up the three-enzyme cascade, we decided to set the temperature at $25^{\circ} \mathrm{C}$ both to avoid heating (and thus reducing energy consumption and process costs), and to increase the half-life of the biocatalysts. This assay was performed in $10 \mathrm{mM}$ phosphate buffer $\mathrm{pH} 7.5(5 \mathrm{~mL})$ containing $2 \mathrm{mM}$ of each reagent (araU, adenine, ATP, $\mathrm{MgCl}_{2}$ ) and the three biocatalysts (CpUP, $6 \mathrm{IU} ; A h \mathrm{PNP}, 15 \mathrm{IU} ; D d \mathrm{dAK}, 0.2 \mathrm{IU}$ ). It is 
worth it to point out that the quantitative conversion of adenine into araA-MP which was achieved under these conditions (reaction assay) confirmed the feasibility of the synthesis by the designed three-enzyme cascade.

As for the reaction $\mathrm{pH}$, immobilized $\mathrm{C} p \mathrm{UP}$ and $A h \mathrm{PNP}$ have an opposite activity profile in the $\mathrm{pH}$ range 6-8. On one hand, at $\mathrm{pH}<7, \mathrm{CpUP}$ loses its activity, on the other hand, when $\mathrm{pH}>8$, the activity of $A h P N P$ dramatically decreases [18]. A balance between activities of both biocatalysts was found at $\mathrm{pH}$ 7.5. This value was also compatible with activity and stability of $D d \mathrm{dAK}$, which was routinely used at $\mathrm{pH} 8$ [12]. Integration of multiple enzymes makes often necessary to switch from the optimal activity and stability $\mathrm{pH}$ and temperature window of each biocatalyst towards a trade-off solution.

\subsubsection{Immobilization Carrier}

In the one-pot transglycosylation reaction catalyzed by $C p \mathrm{UP}$ and AhPNP previously reported [10, 18], it was demonstrated that both enzymes retain their activity and are stable upon immobilization on glyoxyl-agarose under the following operational conditions: $25^{\circ} \mathrm{C}, \mathrm{pH} 7.5,25 \mathrm{mM}$ phosphate buffer containing DMF as co-solvent up to 30\% $v / v$ [18]. On the other side, for the enzymatic phosphorylation of araA previously described by Serra I. et al. [12], immobilization of DddAK on a PEI-coated epoxy carrier (Sepabeads ${ }^{\circledR}$-PEI-CL) was found to generate a positive effect on the catalysis due to the "creation" of an ATP-rich microenvironment. When designing a cascade reaction catalyzed by immobilized enzymes, the immobilization carrier can exert (less or more predictable) effects on the catalysis, depending on its interaction with the other biocatalysts as well as substrates and/or products and/or cofactors with different chemical features (e.g., polarity, presence of net charges etc.). Co-immobilization of enzymes on the same carrier could be desirable for bioconversions involving multi-enzymatic cascade reactions [28]. Such a strategy might overthrow effects deriving from multiple interactions and also mimic "natural" cascade reactions in which enzymes are usually in close proximity to one another [29]. Co-immobilization is frequently used for co-factor-depending enzymes (i.e., oxidoreductases) to fix on the same carrier both the enzyme catalyzing the main biotransformation and an ancillary enzyme responsible for the regeneration of the co-factor [30-33]. However, due to the complexity of this approach for our case-study, we here opted to have the enzymes immobilized on the same carrier, but separately, for individual optimization, taking advantage from the accumulated data on $C p \mathrm{UP}, A h \mathrm{PNP}$ and $D d \mathrm{dAK}$ in the single bioconversions (phosphorolysis, transglycosylation, and phosphorylation) (Figure S1).

To this aim, NPs and DddAK were immobilized, individually, on either glyoxyl-agarose (a) or Sepabeads ${ }^{\circledR}$-PEI-CL (b). These biocatalysts were used for the synthesis of araA-MP and compared with the combination of $C p$ UP and AhPNP immobilized on glyoxyl-agarose and DddAK immobilized on Sepabeads ${ }^{\circledR}$-PEI-CL (c). A fourth combination of differently immobilized enzymes was assayed with the aim to further corroborate the role of the carrier in the modulation of the microenvironment surrounding the enzyme [12]. Therefore, $C p$ UP and $A h P N P$ were immobilized on Sepabeads ${ }^{\circledR}$-PEI-CL and DddAK on glyoxyl-agarose (d). The results achieved in the cascade reaction catalyzed by the three-enzyme systems (a-d) are reported in Table 1 and Figure 1.

Table 1. Synthesis of araA-MP catalyzed by immobilized C $p$ UP, AhPNP and DddAK (reaction assay conditions) ${ }^{1}$.

\begin{tabular}{ccc}
\hline Entry & Immobilization Carrier & Conversion \\
\hline a & Glyoxyl-agarose & $97 \%$ \\
b & Sepabeads ${ }^{\circledR}$-PEI-CL & $56 \%$ \\
c & Glyoxyl-agarose $\left(C p\right.$ UP \& AhPNP) Sepabeads ${ }^{\circledR}$-PEI-CL $(D d d A K)$ & $>99 \%$ \\
d & \left.${\text { Sepabeads }{ }^{\circledR} \text {-PEI-CL }(C p U P \& A h P N P) \text { Glyoxyl-agarose }(D d d A K)}_{39 \%}^{3}\right)$ \\
\hline
\end{tabular}

1 The assay was run at $25^{\circ} \mathrm{C}$ in $10 \mathrm{mM}$ phosphate buffer $\mathrm{pH} 7.5(5 \mathrm{~mL})$ containing araU, adenine, ATP, $\mathrm{MgCl}_{2}$ (2 mM). Biocatalysts: C $p$ UP (6 IU), AhPNP (15 IU), DddAK (0.2 IU). Endpoint: 24 h. Experiments were performed in duplicate. The data points are mean values of duplicate reactions. Deviation from mean values was below $5 \%$ (a and c). A higher deviation from mean values was registered for the enzymatic systems $b$ and $d$. 


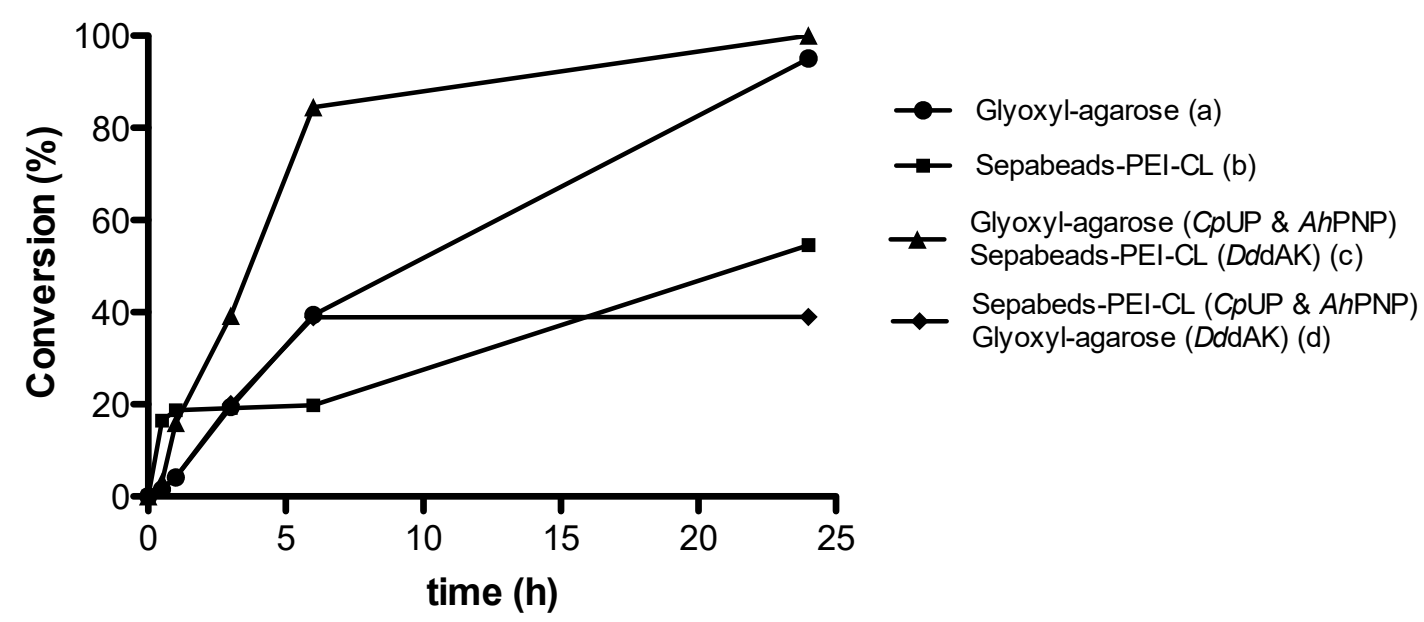

Figure 1. Time course of araA-MP synthesis catalyzed by $C p \mathrm{UP}, A h \mathrm{PNP}$, and DddAK immobilized according to Table 1. Experimental conditions as reported in Table 1 (reaction assay conditions).

Interestingly, quantitative conversions $(>95 \%)$ were observed when all the enzymes were immobilized either on glyoxyl-agarose (entry a, Table 1, and Figure 1), or when NPs were immobilized on glyoxyl-agarose and DddAK on Sepabeads ${ }^{\circledR}$-PEI-CL (entry c, Table 1, and Figure 1). Although a striking difference between the immobilized "systems" (a) and (c) did not emerge, from the inspection of chromatograms at the $6 \mathrm{~h}$-endpoint it is evident that the conversion of araA into araA-MP is slower when all the enzymes are immobilized on glyoxyl-agarose (a) in comparison with the substrate/product profile registered for the biotransformation (c) (see Figure S2, Supplementary Materials).

On the contrary, when all the enzymes were immobilized either on Sepabeads ${ }^{\circledR}$-PEI-CL (entry b), or only the NPs were immobilized on this carrier whereas DddAK was immobilized on glyoxyl-agarose (entry d), the reaction did not achieve the full conversion as for the immobilized systems (a) and (c). Taking into account that all the immobilized biocatalysts were freshly prepared and assayed for their activity before use, we speculated that this result might be ascribed to the effect of the "abundance" of net positive charges deriving from the amount of Sepabeads ${ }^{\circledR}$-PEI-CL in the reaction medium. Although NPs can catalyze the synthesis of araA also when these enzymes are immobilized on Sepabeads ${ }^{\circledR}$-PEI-CL (entries b and d), araA that is progressively formed might be hardly phosphorylated into the corresponding monophosphate as ATP is prone to ionically interact also with the PEI-coating of immobilized NPs, thus becoming less available for the phosphorylation reaction and thus reversing the positive effect of the ATP-rich microenvironment observed both in the mono-enzyme phosphorylation reaction of araA $[11,12]$ and in the cascade derived by the straightforward combination of the three individual reactions (entry c, Table 1, and Figure 1). This behavior is consistent with recent reports on the co-immobilization of phosphorylated cofactors (other than ATP) that results into their homogeneous co-localization across the porous surface of the carrier and their free diffusion between the positively charged surface of the carrier and the active site of the enzyme [24,25]. On these premises, the cascade reaction run by using all the enzymes immobilized on glyoxyl-agarose (entry a, Table 1, and Figure 1) should be not affected by any specific effect due to immobilization microenvironment, neither for the better (entry c) nor for the worse (entries $b$ and d); the final conversion into araA-MP was, indeed, complete, although it proceeded at a rate slower than that of system (c).

All the reactions were monitored up to $24 \mathrm{~h}$. It is worth noting that, whereas the enzyme system (d) appeared to be detrimental for the biotransformation as a whole (the highest conversion, 39\%, was achieved after $6 \mathrm{~h}$ and maintained at $24 \mathrm{~h}$ ), the time course of the reaction catalyzed by the enzyme system (b) suggests that an increase of the reaction conversion over time cannot be ruled out (Figure 1). From the results of the immobilization screening, we opted for the enzyme system (c) to proceed with the reaction scale-up. 


\subsection{Reaction Scale-Up and Product Downstream}

The three-enzyme cascade reaction for the synthesis of araA-MP was scaled-up stepwise from $2 \mathrm{mM}$ up to $25 \mathrm{mM}$ in a final volume of $10 \mathrm{~mL}$ (Figure 2) by using the enzyme system (c) (see Table 1). Quantitative conversions were obtained in all reactions. The reaction scale-up to $25 \mathrm{mM}$ gave $95.5 \%$ conversion after $81 \mathrm{~h}$, corresponding to $82.9 \mathrm{mg}$ of araA-MP.
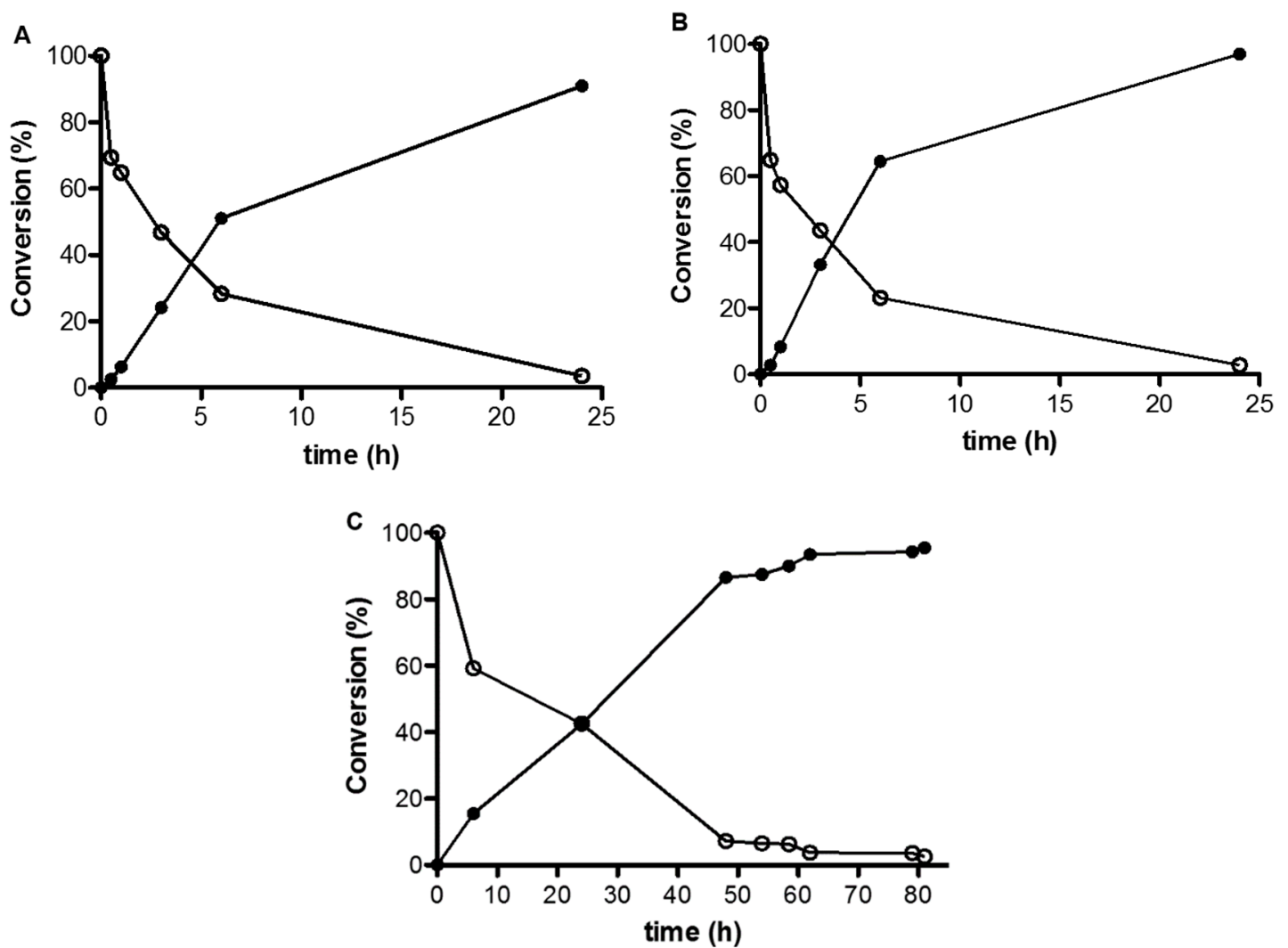

Figure 2. Time course of araA-MP synthesis (scale-up): araA-MP (black circle) and adenine (hollow circle). (A) $5 \mathrm{mM}$, (B) $10 \mathrm{mM}$, (C) $25 \mathrm{mM}$. Experiments were performed in duplicate. The data points are mean values of duplicate reactions. Deviation from mean values was below $5 \%$.

The reaction was purified by semipreparative chromatography affording araA-MP in 55\% yield and $90 \%$ purity. As a result of the progressive adenosine- $5^{\prime}$-monophosphate (ADP) dephosphorylation, the final reaction mixture contained adenosine- $5^{\prime}$-monophosphate (AMP) as the main impurity (besides uracil). Separation of regioisomers AMP and araA-MP is hard to achieve either by chromatography or by other techniques and, in fact, the purification step emerged as the main limiting step of this cascade reaction that would benefit from the use of a catalytic (instead of stoichiometric) amount of ATP and an ATP recycling system [34]. Although a systematic study about recyclability and re-use of the biocatalysts was not carried out yet, the mixture of the immobilized enzymes was used for 2 consecutive reaction cycles and retained completely its activity (the same final conversion was achieved at the endpoint). Moreover, from previous data [18], CpUP and AhPNP immobilized on glyoxyl-agarose were stable up to 5 reaction cycles (1 working week) even in the presence of DMF as the co-solvent, thus suggesting that these biocatalysts are very robust for a repeated use.

\section{Materials and Methods}

All nucleosides and nucleotides were from Sigma-Aldrich and/or Alfa Aesar (Milano, Italy). Solvents, polyethylenimine (PEI) MW 600 and 25,000, dextran MW 6000 [12] and 100,000 [10] were purchased from Sigma-Aldrich or VWR International (Milano, Italy). All solvents were HPLC grade. 
Sepabeads ${ }^{\circledR}$ EC-EP was kindly supplied by Resindion s.r.l. (Binasco, Milano, Italy). Sepharose ${ }^{\mathrm{TM}}$ CL-6B was purchased from Amersham Biosciences AB (Uppsala, Sweden). Regenerated cellulose tubular membrane for dialysis was from Membrane Filtration Products, Inc (Seguin, TX, USA). Biotransformations were monitored by using a HPLC Merck Hitachi L-7100 equipped with a UV detector L-7400 and column oven L-7300 (Darmstadt, Germany). The reaction mixture (from the $25 \mathrm{mM}$ scale-up) was purified by using a preparative Flash Chromatography Reveleris ${ }^{\circledR}$ Purification System (Grace, Columbia, MD, USA and Büchi Italia s.r.l., Cornaredo, Italy) or an AKTA Basic100 Instrument (Pharmacia, Uppsala, Sweden).

Protein concentration assay was performed on a Shimadzu spectrophotometer UV 1601 (Shimadzu, Milan, Italy) by the Bradford method [35] using bovine serum albumin (BSA) as standard. BSA standard was purchased from Sigma-Aldrich (Milano, Italy). AhPNP and $C p \mathrm{UP}$ were prepared as fusion proteins with an $\mathrm{N}$-terminal $\mathrm{His}_{6}$ tag following an established protocol $[9,10]$. DddAK was produced as a fusion protein with a GST-tag, (that was cleaved by using thrombin), as reported by Piškur et al. [36]. Specific activities of free biocatalysts were as follow: AhPNP $39 \mathrm{U} / \mathrm{mg}$, CpUP $68 \mathrm{U} / \mathrm{mg}$, DddAK $1.9 \mathrm{U} / \mathrm{mg}$.

\subsection{Preparation of Sepabeads ${ }^{\circledR}-P E I$ and Aldehyde Dextran}

Sepabeads ${ }^{\circledR}$ PEI and aldehyde dextran were prepared following a standard protocol [8]. Briefly, polyethylenimine (PEI, MW=600 Da or $\mathrm{MW}=25,000 \mathrm{Da})(6.6 \mathrm{~g})$ and $\mathrm{NaCl}(3.76 \mathrm{~g})$ were dissolved in water $(64.3 \mathrm{~mL})$. The $\mathrm{pH}$ was adjusted to 11.0 using $\mathrm{NaOH}$ and then Sepabeads ${ }^{\circledR}$ EC-EP $(5 \mathrm{~g})$ was added. The reaction was carried out for $24 \mathrm{~h}$ at room temperature under mechanical stirring. The suspension was then filtered under reduced pressure and the carrier was first washed with $1 \mathrm{M}$ $\mathrm{NaCl} \mathrm{pH} 11.0$ and then with deionized water. The carrier was stored at $4{ }^{\circ} \mathrm{C}$.

Dextran $(1.67 \mathrm{~g})$ was suspended in deionized water $(50 \mathrm{~mL})$ and different percentages of $\mathrm{NaIO}_{4}$ $(0.435 \mathrm{~g}$ or $0.87 \mathrm{~g})$ were added to obtain $10 \%$ or $20 \%$ of oxidation degree, respectively $[8,11,12]$. The reaction was carried out for $2 \mathrm{~h}$ at room temperature and then the solution was dialyzed (3500 Da molecular weight cut-off, MWCO) against deionized water.

\subsection{Immobilization on Sepabeads ${ }^{\circledR}-P E I$ and Cross-Linking with Aldehyde Dextran. General Procedure}

The immobilization on Sepabeads ${ }^{\circledR}$-PEI was performed as previously reported [8,37]. The activated carrier (Sepabeads ${ }^{\circledR}$-PEI, $1.0 \mathrm{~g}$ ) was suspended in $5 \mathrm{mM}$ potassium phosphate buffer $\mathrm{pH} 7.5$ containing the soluble enzyme (for NPs the loading was $10 \mathrm{mg} / \mathrm{g}$ of carrier, while for DddAK the loading was $1 \mathrm{mg} / \mathrm{g}$ of carrier) in a final volume of $14 \mathrm{~mL}$. The suspension was kept under mechanical stirring at room temperature and, after $1 \mathrm{~h}$, aldehyde dextran $(1.4 \mathrm{~mL})$ was added and allowed to stir for 1 additional hour; the $\mathrm{pH}$ was adjusted to 10.05 using $\mathrm{NaOH}$ (for $D d \mathrm{dAK}$ the temperature was lowered to $4{ }^{\circ} \mathrm{C}$, whereas $A h \mathrm{PNP}$ and $\mathrm{C} p \mathrm{UP}$ were kept at room temperature) and $\mathrm{NaBH}_{4}$ was added $(1 \mathrm{mg} / \mathrm{mL}$ of suspension). The reaction was carried out for $30 \mathrm{~min}$ under mechanical stirring. The immobilized preparations were then filtered and washed with $10 \mathrm{mM}$ potassium phosphate buffer $\mathrm{pH} 5.0$ and deionized water.

\subsection{Preparation of Aldehyde-Agarose (Glyoxyl-Agarose)}

Glyoxyl-agarose was prepared as reported by Guisán et al. [38]. Briefly, agarose (5 g) was suspended in deionized water $(1.4 \mathrm{~mL})$ at $4{ }^{\circ} \mathrm{C}$ under mechanical stirring. A $1.7 \mathrm{M}$ solution of $\mathrm{NaOH}$ $\left(2.4 \mathrm{~mL}\right.$ ) containing $28.5 \mathrm{mg} / \mathrm{mL} \mathrm{NaBH}_{4}$ was added. Etherification was carried out in an ice bath by adding glycidol dropwise $(1.7 \mathrm{~mL})$. The reaction was carried out for $18 \mathrm{~h}$. After the incubation period, the suspension was filtered, and the carrier was washed with deionized water. Oxidation was initiated by adding $100 \mathrm{mM} \mathrm{NaIO}_{4}(34.3 \mathrm{~mL})$. The reaction was carried out for $2 \mathrm{~h}$ at room temperature, then the carrier was filtered under reduced pressure and washed with deionized water and stored at $4{ }^{\circ} \mathrm{C}$. 


\subsection{Immobilization on Aldehyde-Activated Agarose (Glyoxyl-Agarose). General Procedure.}

Immobilization on glyoxyl-agarose was performed following the protocols previously reported [8, 39]. Briefly, glyoxyl-agarose (1 g) was suspended in $100 \mathrm{mM}$ carbonate buffer $(11.1 \mathrm{~mL})$ at $\mathrm{pH} 10.05$. After the addition of the desired amount of protein (the loading was $10 \mathrm{mg} / \mathrm{g}$ of carrier for NPs and $1-2 \mathrm{mg} / \mathrm{g}$ of carrier for $D d \mathrm{dAK})$, the suspension $(14 \mathrm{~mL})$ was kept under mechanical stirring for $3 \mathrm{~h}$. Chemical reduction of Schiff bases was carried out over $30 \mathrm{~min}$ by adding $\mathrm{NaBH}_{4}(14 \mathrm{mg})$ to the mixture. The immobilized enzyme was then filtered and washed with $10 \mathrm{mM}$ phosphate buffer $\mathrm{pH} 5.0$ and deionized water.

\subsection{Enzymatic Activity Assays}

The enzymatic activities of all biocatalysts before and after the immobilization were checked by a standard activity assay, as detailed below.

\subsubsection{NP Activity Assay (Phosphorolysis Reaction)}

Activity of $A h \mathrm{PNP}$ and C $p \mathrm{UP}$ was determined by phosphorolysis [10] using a solution of $50 \mathrm{mM}$ potassium phosphate buffer $\mathrm{pH} 7.5(10 \mathrm{~mL})$ containing the nucleoside substrate $(5 \mathrm{mM}$ inosine for $A h \mathrm{PNP}$ and $5 \mathrm{mM}$ of $2^{\prime}$-deoxyuridine for $C p \mathrm{UP}$, respectively). The reaction was started by adding the enzyme (10-15 mg of immobilized enzyme) and kept under mechanical stirring at room temperature. At different times ( 5 and $10 \mathrm{~min}$ ), samples were withdrawn, filtered using a pipette filter device and analyzed by HPLC (sample dilution 1:5). The chromatographic column was a Kromasil RP18 (5 $\mu \mathrm{m}$, $250 \times 4.6 \mathrm{~mm}$ ); eluent A: $0.01 \mathrm{M}$ phosphate buffer $\mathrm{pH} 4.6$ and eluent $\mathrm{B}: \mathrm{MeOH} 90 \%$; isocratic elution: $97 \% \mathrm{~A}$ and $3 \% \mathrm{~B}$, flow: $1 \mathrm{~mL} / \mathrm{min} ; \mathrm{T}=35^{\circ} \mathrm{C} ; \lambda=260 \mathrm{~nm}$. Retention times: inosine (Ino): $10.8 \mathrm{~min}$; hypoxanthine (Hpx): $5.9 \mathrm{~min}$; 2'-deoxyuridine (dUrd): $8.2 \mathrm{~min}$; uracil (U): $3.9 \mathrm{~min}$. The activity of $A h P N P$ and CpUP was expressed in international units (IU). One IU corresponds to the amount of enzyme that produces $1 \mu \mathrm{mol}$ of product per min at a defined temperature and $\mathrm{pH}$.

$$
\text { Conversion percentage was calculated as follows : } \frac{\text { product peak area }}{(\text { product peak area }+ \text { substrate peak area })} \times 100 \text {. }
$$

\subsubsection{DddAK Activity Assay (Phosphorylation Reaction)}

Activity of DddAK was determined using a solution of $50 \mathrm{mM}$ Tris- $\mathrm{HCl}$ buffer $\mathrm{pH} 8(1 \mathrm{~mL})$ containing $1 \mathrm{mM} 2^{\prime}$-deoxyadenosine (substrate), $2 \mathrm{mM} \mathrm{ATP}$ and $2 \mathrm{mM} \mathrm{MgCl}_{2}$ as previously reported [11, 12]. The reaction was started by adding the enzyme ( $10 \mathrm{mg}$ of immobilized enzyme) and kept under mechanical stirring at $37^{\circ} \mathrm{C}$. At different times (5 and $10 \mathrm{~min}$ ), samples were withdrawn, filtered using a pipette filter device and analyzed by HPLC (sample dilution 1:1). The column was a Kromasil RP18 $(5 \mu \mathrm{m}, 250 \times 4.6 \mathrm{~mm}) \mathrm{kept}$ at $35^{\circ} \mathrm{C}$, the flow rate was $1 \mathrm{~mL} / \mathrm{min}$. Mobile phase: eluent A: $2 \mathrm{~g} \mathrm{NH}_{4} \mathrm{H}_{2} \mathrm{PO}_{4}+0.5 \mathrm{~g}\left(\mathrm{NH}_{4}\right)_{2} \mathrm{HPO}_{4}$ dissolved in $1 \mathrm{~L}$ of bi-distilled water $+30 \mathrm{~mL} \mathrm{MeOH}$; eluent $\mathrm{B}$ : $\mathrm{CH}_{3} \mathrm{CN} 90 \%$; gradient elution: $0(100 \% \mathrm{~A})-8 \mathrm{~min}$. (100\% A)-22 min. (70\% A-30\% B)-23 $\mathrm{min} .(100 \% \mathrm{~A})$. Retention times: adenosine triphosphate (ATP): $3.2 \mathrm{~min}$; adenosine diphosphate (ADP): $3.6 \mathrm{~min}$; adenosine monophosphate (AMP): $5.9 \mathrm{~min}$; 2'-deoxyadenosine (dAdo): $16.5 \mathrm{~min}$; 2'-deoxyadenosine monophosphate (dAdo-MP): $10.0 \mathrm{~min}$. The activity of $D d \mathrm{~d} A K$ was expressed in IU. One IU corresponds to the amount of enzyme that produces $1 \mu \mathrm{mol}$ of dAdo-MP per min at a defined temperature and $\mathrm{pH}$.

Conversion percentage was calculated as follows : $\frac{\text { product peak area }}{(\text { product peak area }+ \text { substrate peak area })} \times 100$.

\subsection{Synthesis of araA-MP (Analytical Scale)}

A solution of $10 \mathrm{mM}$ potassium phosphate buffer $\mathrm{pH} 7.5(5 \mathrm{~mL})$ containing araU, Ade, ATP, $\mathrm{MgCl}_{2}$ $(2 \mathrm{mM})$ was prepared. The reaction was started by adding the enzymes (6 IU CpUP, 15 IU AhPNP, $0.2 \mathrm{IU} D d \mathrm{dAK})$ and kept under mechanical stirring at $25^{\circ} \mathrm{C}$ or $37^{\circ} \mathrm{C}$. At different times $(30 \mathrm{~min}, 1 \mathrm{~h}, 3 \mathrm{~h}$, 
$6 \mathrm{~h}$ and $24 \mathrm{~h}$ ), samples were withdrawn, filtered using a pipette filter device and analyzed by HPLC (sample dilution 1:1). The reaction was repeated by using a $5 \mathrm{mM}$ concentration of the reagents in a $10 \mathrm{~mL}$ final volume (15 IU CpUP, $37.5 \mathrm{IU} A h \mathrm{PNP}, 0.5 \mathrm{IU} D d \mathrm{dAK}$ ), and further scaled-up to $10 \mathrm{mM}$ (30 IU C $p$ UP, 75 IU AhPNP, 1 IU DddAK). Concentration of $\mathrm{MgCl}_{2}$ was kept constant (2 mM).

The synthesis of araA-MP was monitored by HPLC at $260 \mathrm{~nm}$ as reported in paragraph 3.5.2. [11,12]. Retention times: adenosine triphosphate (ATP): $3.2 \mathrm{~min}$; adenosine diphosphate (ADP): $3.6 \mathrm{~min}$; uracil (U): $4.3 \mathrm{~min}$; adenosine monophosphate (AMP): $5.9 \mathrm{~min}$; vidarabine monophosphate (araA-MP): $6.4 \mathrm{~min}$; arabinosyluracil (araU): $10.2 \mathrm{~min}$; adenine (Ade): $12.6 \mathrm{~min}$; vidarabine (araA): $16.5 \mathrm{~min}$. All products were identified by comparing their retention times with those of authentic samples. The percentage of conversion was calculated from the depletion of Ade (substrate) and monitoring the formation of the nucleotide (araA-MP, product): The percentage of conversion of the multi-enzymatic reaction was calculated as follows: $\frac{\text { araA-MP peak area }}{(\text { araA-MP peak area }+ \text { adenine peak area })} \times 100$.

\subsection{Synthesis of araA-MP (Scale-Up)}

To a solution $(10 \mathrm{~mL})$ of $10 \mathrm{mM}$ potassium phosphate buffer araU $(61.05 \mathrm{mg}, 25 \mathrm{mM})$, Ade $(33.78 \mathrm{mg}$, $25 \mathrm{mM})$, ATP (137.75 mg, $25 \mathrm{mM})$ and $\mathrm{MgCl}_{2}(1.9 \mathrm{mg}, 2 \mathrm{mM})$ were added. The final $\mathrm{pH}$ was set to 7.5 with diluted $\mathrm{NaOH}$. The immobilized enzymes (30 IU CpUP, 75 IU AhPNP, 1 IU DddAK) were then added and the mixture was kept under mechanical stirring at $25^{\circ} \mathrm{C}$. The reaction was monitored by HPLC (see paragraph 3.6 for chromatographic conditions and $t_{R}$ ). Once the conversion was complete $(81 \mathrm{~h})$, the reaction was stopped by filtering off the enzymes. Purification of araA-MP was accomplished by preparative HPLC using an AKTA Basic100 Instrument (Pharmacia, Uppsala, Sweden) (a) or a Flash Chromatography Reveleris ${ }^{\circledR}$ Purification System (b). Chromatographic conditions were as follows: (a) column, Phenomenex Jupiter RP18 $(10 \mu \mathrm{m}, 250 \times 10 \mathrm{~mm}$, Merck); flow rate, $5 \mathrm{~mL} / \mathrm{min}$; $\lambda, 260 \mathrm{~nm}$ and $280 \mathrm{~nm}$; mobile phase $\mathrm{A}=20 \mathrm{mM}\left(\mathrm{NH}_{4}\right) \mathrm{HCO}_{3} \mathrm{pH} 5$ and $\mathrm{B}=\mathrm{MeOH}$, isocratic elution: $3 \% \mathrm{MeOH}$ for 2 column volumes, followed by a gradient elution from $3 \%$ to $40 \% \mathrm{MeOH}$ in 2 column volumes; (b) column, Vydac 150HC RP18 $(10 \mu \mathrm{m}, 150 \times 20 \mathrm{~mm}$, Grace); flow rate:, $10 \mathrm{~mL} / \mathrm{min} ; \lambda, 260 \mathrm{~nm}$ and $280 \mathrm{~nm}$; mobile phase $\mathrm{A}=20 \mathrm{mM}\left(\mathrm{NH}_{4}\right) \mathrm{HCO}_{3} \mathrm{pH} 5+2 \% \mathrm{MeOH}$ and $\mathrm{B}=\mathrm{MeOH}$, isocratic elution: 100\% A, step gradient to $30 \%$ B at 20 min. Purified fractions were freeze-dried (white solid). Yield $=51-55 \%$. The product was analyzed by HPLC (see paragraph 3.6) resulting in a mixture of araA-MP and AMP ( $82 \%$ and $18 \%$, respectively). Further purification runs afforded the title product with a purity (HPLC) of $90 \%$, being AMP the only contaminant.

\section{Conclusions}

In this work the synthesis of vidarabine-5'-monophosphate was successfully redesigned through a multi-enzymatic one-pot cascade reaction. Two NPs ( $C p U P$ and $A h P N P)$ endowed with a different substrate specificity (for pyrimidine nucleosides and purine nucleosides, respectively) were coupled to a deoxyribonucleoside kinase whose substrate specificity was directed exclusively toward adenine nucleosides. Orchestration of enzyme substrate specificity played a key role for the feasibility of the biotransformation along with tuning of the reaction and immobilization conditions. Substrates were fully converted into the target compound in aqueous medium at $25^{\circ} \mathrm{C}$ and $\mathrm{pH} 7.5$, thus paving the way for the true optimization of this reaction which might be applied to the synthesis of other 5 '-mononucleotides, such as the antileukemia agent fludarabine-5'-monophosphate. In this frame, this "tandem" multi-enzymatic biotransformation will need to be engineered by adding to the cascade an in situ ATP regeneration system, both to reduce the amount of ATP necessary as the phosphate donor and to control AMP formation as the main by-product (besides uracil). Nevertheless, the cascade reaction here described is the first example reported to date for easily accessing nucleotide $5^{\prime}$-monophosphates based on the concurrent use of NPs and deoxyribonucleoside kinases. This reaction design could be exploited, indeed, after an enzymatic screening, for the synthesis of other high-added value nucleoside- $5^{\prime}$-monophosphates. 
Supplementary Materials: The following are available online at http://www.mdpi.com/2073-4344/10/1/60/s1, Figure S1: Comparison between the proposed three-enzyme cascade system and the previously reported transglycosylation [18] and phosphorylation [12] reactions. Figure S2: HPLC chromatograms of the multi-enzyme cascade reaction catalyzed by NPs and DddAK immobilized on glyoxyl-agarose (system a), and NPs on glyoxyl-agarose and DddAK on Sepabeads ${ }^{\circledR}$-PEI-CL (system c) (endpoint: $6 \mathrm{~h}$ ).

Author Contributions: Methodology, investigation, and writing (original draft preparation, review and editing), M.S.R.; investigation, supervision, and critical review of the manuscript, I.S.; conceptualization, M.T.; conceptualization, investigation, data curation, supervision, writing (original draft preparation, review and editing), D.U.; investigation, T.B. All authors have read and agreed to the published version of the manuscript.

Funding: This research received no external funding.

Acknowledgments: We thank Giovanna Speranza (Department of Chemistry, University of Milano, Italy) for fruitful discussion, and Giulia Cattaneo (Department of Drug Sciences, University of Pavia, Italy) for her assistance in purification of vidarabine $5^{\prime}$-monophosphate. Resindion s.r.l. (Binasco, Milano, Italy) is gratefully acknowledged for the supply of Sepabeads ${ }^{\circledR}$ EC-EP.

Conflicts of Interest: The authors declare no conflict of interest.

\section{References}

1. Jordheim, L.P.; Durantel, D.; Zoulim, F.; Dumontet, C. Advances in the development of nucleoside and nucleotide analogues for cancer and viral diseases. Nat. Rev. Drug Discov. 2013, 12, 447-464. [CrossRef] [PubMed]

2. Chaudhuri, S.; Symons, J.A.; Deval, J. Innovation and trends in the development and approval of antiviral medicines: 1987-2017 and beyond. Antiviral Res. 2018, 155, 76-88. [CrossRef] [PubMed]

3. Seley-Radtke, K.L.; Yates, M.K. The evolution of nucleoside analogue antivirals: A review for chemists and non-chemists. Part 1: Early structural modifications to the nucleoside scaffold. Antiviral Res. 2018, 154, 66-86. [CrossRef] [PubMed]

4. De Clercq, E.; Li, G. Approved antiviral drugs over the past 50 years. Clin. Microbiol. Rev. 2016, $29,695-747$. [CrossRef] [PubMed]

5. Tamamyan, G.; Kadia, T.; Ravandi, F.; Borthakur, G.; Cortes, J.; Jabbour, E.; Daver, N.; Ohanian, M.; Kantarjian, H.; Konopleva, M. Frontline treatment of acute myeloid leukemia in adults. Crit. Rev. Oncol. Hematol. 2017, 110, 20-34. [CrossRef]

6. Glaudemans, G.P.J.; Fletcher, H.G. Syntheses with partially benzylated sugars. III. A simple pathway to a cis-nucleoside, 9- $\beta$-D-arabinofuranosyladenine (spongoadenosine). J. Org. Chem. 1963, 28, 3004-3006. [CrossRef]

7. Moreau, C.; Ashamu, G.A.; Bailey, V.C.; Galione, A.; Guse, A.H.; Potter, B.V.L. Synthesis of cyclic adenosine 5'-diphosphate ribose analogues: A C2' endo/syn "southern" ribose conformation underlies activity at the sea urchin cADPR receptor. Org. Biomol. Chem. 2011, 9, 278-290. [CrossRef]

8. Rocchietti, S.; Ubiali, D.; Terreni, M.; Albertini, A.M.; Fernández-Lafuente, R.; Guisán, J.M.; Pregnolato, M. Immobilization and stabilization of recombinant multimeric uridine and purine nucleoside phosphorylases from Bacillus subtilis. Biomacromolecules 2004, 5, 2195-2200. [CrossRef]

9. Ubiali, D.; Serra, C.D.; Serra, I.; Morelli, C.F.; Terreni, M.; Albertini, A.M.; Manitto, P.; Speranza, G. Production, characterization and synthetic application of a purine nucleoside phosphorylase from Aeromonas hydrophila. Adv. Synth. Catal. 2012, 354, 96-104. [CrossRef]

10. Serra, I.; Ubiali, D.; Piškur, J.; Christoffersen, S.; Lewkowicz, E.S.; Iribarren, A.M.; Albertini, A.M.; Terreni, M. Developing a collection of immobilized nucleoside phosphorylases for the preparation of nucleoside analogues: Enzymatic synthesis of arabinosyladenine and $2^{\prime}, 3^{\prime}$-dideoxyinosine. ChemPlusChem 2013, 78 , 157-165. [CrossRef]

11. Serra, I.; Conti, S.; Piškur, J.; Clausen, A.R.; Munch-Petersen, B.; Terreni, M.; Ubiali, D. Immobilized Drosophila melanogaster deoxyribonucleoside kinase $(D m \mathrm{dNK})$ as a high performing biocatalyst for the synthesis of purine arabinonucleotides. Adv. Synth. Catal. 2014, 356, 563-570. [CrossRef]

12. Serra, I.; Ubiali, D.; Piškur, J.; Munch-Petersen, B.; Bavaro, T.; Terreni, M. Immobilization of deoxyadenosine kinase from Dictyostelium discoideum (DddAK) and its application in the $5^{\prime}$-phosphorylation of arabinosyladenine and arabinosyl-2-fluoroadenine. ChemistrySelect 2017, 2, 5403-5408. [CrossRef] 
13. Fernández-Lucas, J.; Camarasa Rius, M.J. Enzymatic and Chemical Synthesis of Nucleic Acid Derivatives, 1st ed.; Wiley-VCH Verlag GmbH \& Co. KGaA: Weinheim, Germany, 2018; pp. 1-325.

14. Slot Christiansen, L.; Munch-Petersen, B.; Knecht, W. Non-viral deoxyribonucleoside kinases-diversity and practical use. J. Genet. Genomics 2015, 42, 235-248. [CrossRef]

15. Zhou, X.; Szeker, K.; Jiao, L.-Y.; Oestreich, M.; Mikhailopulo, I.A.; Neubauer, P. Synthesis of 2,6-dihalogenated purine nucleosides by thermostable nucleoside phosphorylases. Adv. Synth. Catal. 2015, 357, 1237-1244. [CrossRef]

16. Zhou, X.; Yan, W.; Zhang, C.; Yang, Z.; Neubauer, P.; Mikhailopulo, I.A.; Huang, Z. Biocatalytic synthesis of seleno-, thio- and chloro-nucleobase modified nucleosides by thermostable nucleoside phosphorylases. Catal. Commun. 2019, 121, 32-37. [CrossRef]

17. Hellendahl, K.F.; Kamel, S.; Wetterwald, A.; Neubauer, P.; Wagner, A. Human deoxycytidine kinase is a valuable biocatalyst for the synthesis of nucleotide analogues. Catalysts 2019, 9, 997. [CrossRef]

18. Serra, I.; Daly, S.; Alcantara, A.R.; Bianchi, D.; Terreni, M.; Ubiali, D. Redesigning the synthesis of vidarabine via a multienzymatic reaction catalyzed by immobilized nucleoside phosphorylases. RSC Adv. 2015, 5, 23569-23577. [CrossRef]

19. Schrittwieser, J.H.; Velikogne, S.; Hall, M.; Kroutil, W. Artificial biocatalytic linear cascades for preparation of organic molecules. Chem. Rev. 2018, 118, 270-348. [CrossRef]

20. Sperl, J.M.; Sieber, V. Multienzyme cascade reactions-status and recent advances. ACS Catal. 2018, 8, 2385-2396. [CrossRef]

21. Claaßen, C.; Gerlach, T.; Rother, D. Stimulus-responsive regulation of enzyme activity for one-step and multi-step syntheses. Adv. Synth. Catal. 2019, 361, 2387-2401. [CrossRef]

22. France, S.P.; Hepworth, L.J.; Turner, N.J.; Flitsch, S.L. Constructing biocatalytic cascades: In vitro and in vivo approaches to de novo multi-enzyme pathways. ACS Catal. 2017, 7, 710-724. [CrossRef]

23. Ji, Q.; Wang, B.; Tan, J.; Zhu, L.; Li, L. Immobilized multienzymatic systems for catalysis of cascade reactions. Process Biochem. 2016, 51, 1193-1203. [CrossRef]

24. Bonomi, P.; Bavaro, T.; Serra, I.; Tagliani, A.; Terreni, M.; Ubiali, D. Modulation of the microenvironment surrounding the active site of penicillin $\mathrm{G}$ acylase immobilized on acrylic carriers improves the enzymatic synthesis of cephalosporins. Molecules 2013, 18, 14349-14365. [CrossRef] [PubMed]

25. Velasco-Lozano, S.; Benítez-Mateos, A.I.; López-Gallego, F. Co-immobilized phosphorylated cofactors and enzymes as self-sufficient heterogeneous biocatalysts for chemical processes. Angew. Chem. Int. Ed. 2017, 56, 771-775. [CrossRef] [PubMed]

26. Benítez-Mateos, A.I.; Contente, M.L.; Velasco-Lozano, S.; Paradisi, F.; López-Gallego, F. Self-sufficient flow-biocatalysis by coimmobilization of pyridoxal $5^{\prime}$-phosphate and $\omega$-transaminases onto porous carriers. ACS Sustain. Chem. Eng. 2018, 6, 13151-13159. [CrossRef]

27. Tacias-Pascacio, V.G.; Ortiz, C.; Rueda, N.; Acosta, N.; Aranaz, I. Dextran aldehyde in biocatalysis: More than a mere immobilization system. Catalysts 2019, 9, 622. [CrossRef]

28. Ren, S.; Li, C.; Jiao, X.; Jia, S.; Jiang, Y.; Bilal, M.; Cui, J. Recent progress in multienzymes co-immobilization and multienzyme system applications. Chem. Eng. J. 2019, 373, 1254-1278. [CrossRef]

29. Luo, J.; Meyer, A.S.; Mateiu, R.V.; Pinelo, M. Cascade catalysis in membranes with enzyme immobilization for multi-enzymatic conversion of $\mathrm{CO}_{2}$ to methanol. New Biotechnol. 2015, 32, 319-3279. [CrossRef]

30. Garny, S.; Beeton-Kempen, N.; Gerber, I.; Verschoor, J.; Jordaan, J. The co-immobilization of P450-type nitric oxide reductase and glucose dehydrogenase for the continuous reduction of nitric oxide via cofactor recycling. Enzyme Microb. Technol. 2016, 85, 71-81. [CrossRef]

31. Li, H.; Xiao, W.; Xie, P.; Zheng, L. Co-immobilization of enoate reductase with a cofactor-recycling partner enzyme. Enzyme Microb. Technol. 2018, 109, 66-73. [CrossRef]

32. Solé, J.; Caminal, G.; Schürmann, M.; Álvaro, G.; Guillén, M. Co-immobilization of P450 BM3 and glucose dehydrogenase on different supports for application as a self-sufficient oxidative biocatalyst. J. Chem. Technol. Biotechnol. 2018, 94, 244-255. [CrossRef]

33. Petrovicová, T.; Markošová, K.; Hegyi, Z.; Smonou, I.; Rosenberg, M.; Rebroš, M. Co-immobilization of ketoreductase and glucose dehydrogenase. Catalysts 2018, 8, 168. [CrossRef]

34. Faber, K. Biotransformations in Organic Chemistry: A Textbook, 6th ed.; Springer: Berlin/Heidelberg, Germany, 2011; pp. 1-423. 
35. Bradford, M.M. A rapid and sensitive method for the quantitation of microgram quantities of protein utilizing the principle of protein-dye binding. Anal. Biochem. 1976, 72, 248-254. [CrossRef]

36. Sandrini, M.P.B.; Söderbom, F.; Mikkelsen, N.E.; Piškur, J. Dictyostelium discoideum salvages purine deoxyribonucleosides by highly specific bacterial-like deoxyribonucleoside kinases. J. Mol. Biol. 2007, 369, 653-664. [CrossRef]

37. Serra, I.; Serra, C.D.; Rocchietti, S.; Ubiali, D.; Terreni, M. Stabilization of thymidine phosphorylase from Escherichia coli by immobilization and post immobilization techniques. Enzyme Microb. Technol. 2011, 49, 52-58. [CrossRef]

38. Guisán, J.M. Aldehyde-agarose gels as activated supports for immobilization-stabilization of enzymes. Enzyme Microb. Technol. 1988, 10, 375-382. [CrossRef]

39. Mateo, C.; Palomo, J.M.; Fuentes, M.; Betancor, L.; Grazu, V.; López-Gallego, F.; Pessela, B.C.C.; Hidalgo, A.; Fernández-Lorente, G.; Fernández-Lafuente, R.; et al. Glyoxyl agarose: A fully inert and hydrophilic support for immobilization and high stabilization of proteins. Enzyme Microb. Technol. 2006, 39, 274-280. [CrossRef]

(C) 2020 by the authors. Licensee MDPI, Basel, Switzerland. This article is an open access article distributed under the terms and conditions of the Creative Commons Attribution (CC BY) license (http://creativecommons.org/licenses/by/4.0/). 